\title{
Conceptual Support of the Modern Educational Process
}

\author{
Svetlana Popova* , Elena Kokoreva, and Konstantin Kirsanov \\ Institute of World Civilizations, Moscow, Russian Federation
}

\begin{abstract}
The article discusses the conceptual directions of the development of education: all-age and continuous. Two interrelated basic tendencies of all-age education have been identified. The authors considered the specificity of educational concepts in different countries of the world. Depending on the level of embeddedness of research competence in the activity, a morphological five-aspect classification is proposed. The following aspects of the division were identified as independent: mental orientation of the individual to the implementation of research activities; own (individual) motivational apparatus that stimulates a person to carry out research activities; the level of requirements and the presence of high-quality psychological support of the close external environment for the formation of acquired properties (signs) in a person for the implementation of expedient research activities; the level of requirements and the presence of high-quality psychological support of the distant external environment for the formation of acquired properties (signs) in a person for the implementation of expedient research activities; the presence of a methodological and informational apparatus in an educational institution for identifying congenital and acquired personality inclinations to research activities. The system of research competence for a specific educational institution, including various aspects of its functioning, is presented by the authors in a code dimension (one of the basic requirements of the digital economy). A sequence of development of a code portrait is proposed, which allows the entire set of educational institutions to be divided according to the level of the state of the system of research competence, which gives the management apparatus of the university a powerful mechanism for the formation of acquired properties (attributes) in a person to carry out expedient research activities (creating the necessary volume and focus of research competence of students and trainees). Based on the proposed methodology, a comparison was made between two educational systems: domestic (Russian) and foreign (American).
\end{abstract}

\section{Introduction}

In modern society, education is one of the vast areas of human activity. It is believed that the modern education system at the beginning of the new millennium in the world

\footnotetext{
* Corresponding author: svetpopzhuk@yandex.ru
} 
employed more than a billion students and almost 50 million teachers. Both social and economic role of education is extremely high. A technological breakthrough and widespread dissemination of information technologies, the development of electronic and distance learning, lead to the need to reform and modernize education systems in many countries of the world within the framework of its modern conceptual support.

There is and is progressing the problem of rethinking the existing methodological approaches to the formation of pedagogical technologies in the modern education system. At the moment, it is advisable not so much to criticize and abandon the existing developments, but to use a methodology that involves the integration of a new vision, existing and proven educational approaches. The comparative analysis carried out (various approaches to existing and new pedagogical technologies in the modern education system with the development of proposals for creating a new approach to the development of the education system, including additional, distance education of the sixth generation) should proceed from the formation of ideas that the educational system is vertically integrated structure and that the quality of education at each level has its own methodological basis for the definition.

Currently, the education system plays a strategic role in the socio-economic development of any country. First of all, the economy needs competent personnel, which requires a certain way to modernize the education system in the direction of lifelong education for all ages. Therefore, at the moment there is a need to create a system for assessing the quality of education in the mode of continuous automated monitoring with regulation of the selection and use of criteria, quantitative and qualitative indicators for external and internal audit.

The study of the creation of a system for assessing the quality of education in the mode of continuous automated monitoring with the regulation of the selection and use of criteria, quantitative and qualitative indicators for external and internal audit was carried out using general scientific methods of knowledge, including analysis, synthesis, aggregation.

The study of the dependence on the level of embeddedness of research competence in activities was carried out using the theoretical apparatus of morphological analysis.

On the basis of an expert assessment, the values of various aspects of division were determined for the formation of acquired properties (signs) in a person for the implementation of expedient research activities.

A comparative analysis of expert code portraits of educational institutions in Russia and the United States is carried out.

\section{Results and discussion}

Currently, the following conceptual directions for the development of education are distinguished:

1) all-age;

2) continuous.

The construction of an all-age concept of education is associated with its seven-level division of the educational sphere into: nursery, preschool, school, youth (receiving either secondary or higher education, or both), transitional, adult. Thus, the branches of pedagogy (currently scattered) need to generalize and form the general pedagogy of the sixth generation, which should make it possible to change the principles of development of additional education and vocational guidance.

All-age education is the interaction of two basic trends in modern education.

The first tendency is that education accompanies a person throughout his life, from birth to retirement from the life cycle. Life and professional activity are constantly updated, there 
is a need to regulate new functions, new educational practices appear, and the role of human capital is growing. Education permeates work and play for full experiences.

The second trend is that education becomes symbiosis due to the formation of an individual trajectory of development while simultaneously being implemented in a constantly changing team (team, group, school) and is based on mutual assistance and joint projects.

The combined two of these tendencies represent a constantly changing essential characteristics (primarily intellectual and competence) education and team project education, a new system of interaction between generations of people living in the field of distance additional education of different technological generations is being formed.

As for the concept of lifelong education, it is a general international concept in the field of education. The UNESCO International Committee for the Development of Education has come to the conclusion that lifelong education should become the general concept of education. "Every person should learn all his life. Education must continue at any age ... in accordance with the needs of the individual ... We propose continuing education as a general concept for an educational strategy for many years to come ... The concept of continuing education covers all aspects of education, and the whole is much more than a simple sum of its constituent parts" [1].

Within the framework of the designated concepts, we will consider the specifics of educational concepts in different countries of the world.

USA. One of the leaders in distance education today is the United States, which owns about $50 \%$ of this market. $80 \%$ of the 2,600 US higher education institutions $(2,080$ universities) provide full or partial online education. The most popular among them are currently: Boston, Florida, Arizona universities.

As defined by the Babson Survey Research Group, "Distance education is education that uses one or more technologies to maintain regular interaction between students and the teacher, either synchronously or asynchronously. Technologies used for education today may include: the Internet, one-way and two-way transmission through open radio transmissions, closed circuits, cable, microwave, broadband, fiber-optic, satellite or wireless communication devices; audio conferencing; digital data carriers used in addition to the listed technologies" [2]. 5]:

The concept of the distance education system is based on the following principles $[3,4$,

1) The principle of interactivity and communicative saturation - information and communication interaction of educational subjects, for example, using such digital technologies and tools as videoconferences, webinars, forums, blogs, social networks, etc.

2) Priority of the pedagogical approach - the basis is the didactic requirements for the process and the result of learning when using certain technical support.

3) The principle of pedagogical expediency of using new information technologies means the expediency of using information technologies and technical facilities in accordance with the goals of education.

4) The principle of modularity - training should be based on separate modules, a complete block that integrates various types and forms of training.

5) The principle of openness and accessibility - the possibility of using distance education for different age groups of the population anywhere in the world.

6) The principle of flexibility and dynamism - ensuring the individual work of students, taking into account the personal qualities of each.

7) The principle of mobility - the creation of a system of information and communication technologies that allow students to supplement the educational program in the required direction. 
8) The principle of technical support is to provide high-quality technical support

vivid functioning of the training course.

In 2012, Massive Open Online Course (MOOC) became widespread. It is the US universities that show the best indicators of activity in the development of such online courses - on average, one American university places a total of 34 courses on the two platforms under consideration.

Canada. Canada is another leader in the use of distance education.

One of the approaches to creating a digital educational environment used in Canada is virtual academic mobility of students, the use of which, since the 70s. of the last century, allowed her to accumulate quite a lot of experience in this area and get a long-term practice of international academic cooperation at the federal and provincial levels.

Currently, academic mobility of students acts as a guarantee of the existence and development of educational institutions in Canada, creating an unlimited information space that allows students to exchange best practices.

In the system of higher education in Canada, there are several stages in the development of academic mobility relative to its participants [6]:

- initial - international and national organizations;

- transitional - international and national organizations;

- integration - the provincial governments of Canada;

- strategic - the federal government of Canada.

The subjects of virtual academic mobility are [6]:

1) "virtual student" (from the English Virtual student or online learner) - a student who is a participant in virtual academic mobility;

2) "virtual teacher" (from the English. Virtual professor) - the teacher of the course, which is offered virtually;

3) "virtual university" (from the English. Virtual university) - a higher educational institution that offers an online course;

4) "virtual campus" (from the English. Virtual campus) - a website consisting of two parts: a virtual space opens to all users and a closed virtual space. If the user entered the site without registering, he sees the open part of the site. Access to the closed part of the site, on which the training takes place, is given after enrolling in a distance learning course.

European Union countries. As for the EU countries, their "modern strategy is based on the recognition of the fact that education and vocational training play a key role in solving many socio-economic, demographic, environmental and technological problems in Europe in the present and in the future; effective investment in human capital through education and vocational training systems is necessary to ensure the sustainable development of societies" [7].

The document "Memorandum of Life-Long Education" (2000) formulates the main postulates that should correspond to lifelong education in the era of building the information society:

1) Availability of knowledge for all, which should be ensured through universal and continuous access to learning and increasing knowledge, skills and abilities required for the digital society.

2) Increased investment in human potential.

3) Leveraging innovation in teaching and learning: developing effective teaching and learning methods in lifelong learning.

4) Rethinking the role of teaching and learning in formal and non-formal education.

5) Rethinking the availability of educational technologies and information resources, advising on the possibilities of obtaining education throughout life. 
6) Providing accessible education through the use of information and communication technologies.

According to the provisions of the Memorandum, lifelong education should acquire the status of the main principle of the educational process, capable of ensuring all residents of Europe participate in various forms of education.

At the same time, in the countries of the European Union, the presence of a huge conservatism of the entire education system is recorded, which is manifested in the preservation of approaches to understanding the goals and objectives of pedagogical technologies, despite the fact that everyone supports an understanding of the continuity of the learning process throughout life.

Germany. The main conceptual approach in the field of innovative development of education in Germany is the concept of the "triple helix", which provides for the interaction of such institutional areas as the state, universities and business to effectively use innovative opportunities.

The Triple Helix makes it possible to move from one institutional area to another, thus giving rise to an innovation process.

South Korea. The creation of a successful unique innovative education system in South Korea is based on the American concept of the development of the higher education system, supplemented by a combination of scientific research with business culture [8].

In 2009-2010 Ministry of Education of the Republic of Korea initiated

an international project to create the ASEAN Cyber University, which includes the best universities in South Korea, Burma, Vietnam, Cambodia, Laos, Thailand. The main goal of this project is to help strengthen higher education in the ASEAN region through digital education, thereby strengthening international ties between the countries of this association.

In 2010, Hanyang Cyber University became the first accredited Cyber University. Cyber University has developed a total of 12 programs, taking into account the needs and demands of customers, training for which is recognized in all member countries of the association.

In the Bloomberg rating of innovative countries, from 2015 to 2019, South Korea held 1st place, in 2020 - 2nd, showing the greatest innovation potential among 50 countries of the world.

A conceptual innovative approach used in South Korea is the introduction of a new education system based on IT development - "smart education" or "smart learning" [9].

The main concept of smart education is that the teacher's functions include only coordination and guidance of the educational process. Students get access to instructional content (media files, mobile applications, presentations, e-manuals, etc.) online.

The technological platform for smart learning is the cloud computing model, which provides ubiquitous and convenient network access to a shared pool of configurable computing resources: data networks, servers, storage devices, applications and services. ... Thus, smart learning is implemented in almost all areas of education and gives students the opportunity to learn without restrictions.

China. Chinese universities are implementing their own educational strategy, focusing both on the domestic market of scientific and educational services, and on the external one, and are aimed at achieving those indicators and in those areas that are prescribed for them by state programs with targeted funding on a competitive basis. Thus, the policy of the state is aimed at stimulating the scientific and educational activities of universities, taking into account world trends.

The main feature of the formation of a strategy for the development of higher education in China is the creation of a world-class university with Chinese characteristics. So, starting in 2016, the development strategies of universities in China include such elements as big 
data and artificial intelligence, implemented in the format of specially created laboratories or centers in conjunction with universities in the United States, Germany and Japan.

According to the Strategy "Made in China 2025", approved in 2015, the main areas within which the active digitalization of the country is supposed to be energy, agriculture, education, health care, transport, financial services, social and public services, logistics, ecommerce, development of the "experience economy", intellectual property management, software development, including open source software.

It should be noted that the strategies for the development of education in China lack social adaptation or gerontological education, which is associated with the culture of China, where the older generation is usually assigned the role of guardians of the hearth and family.

In Russia, there is no experience in the implementation of advanced analysis of the organization of education management systems, taking into account the existing processes of harmonization (and not just copying and subordination) with other countries. At the same time, the need to create a system for assessing the quality of education in the mode of continuous automated monitoring with the regulation of the selection and use of criteria, quantitative and qualitative indicators for external and internal audit, is properly recognized. This, in turn, requires formalizing the theoretical provisions on how:

- scientific ideas and modern methodology of interaction of educational approaches (knowledge and competence) are being formed and why, despite the enormous efforts on the part of the scientific community, these approaches did not lead to a sharp jump in the quality of education;

- there is a realization that only the creation of a functional approach (together with knowledge and competence, and not in isolation from them), which (in its aggregate with the previous ones) allows at a new level to influence the processes of transition to the sixth technological order and that additional remote education of the new generation is the foundation on which most of the pedagogical technologies should be built;

- the methodology of organizing activities is changing (in particular, universities, colleges, gymnasiums, colleges, etc.) for the transition to a qualitatively new approach to the formation of pedagogical technologies (mastering the basic provisions of the "educational revolution" by creating a new vision of the development of the educational sphere) associated with the processes of transition to the sixth technological order;

- organization of active the principles and scientific substantiation of the development of breakthrough technologies by educational institutions, not only of a technical nature, but also for other spheres of human life (society), which directly affect the processes (of a very different nature and type) of the transition to the sixth technological order;

- carry out projects that include the development of scientific, technological and environmental and social forecasts of innovative (taking into account the widespread development of breakthrough technologies associated with the processes of transition to the sixth technological order) development of the region (country, unification of countries), in which educational institutions are located, and their capabilities for multidimensional influence on the ongoing processes.

The formation of the information environment in the country (region), and, as a consequence, educational institutions and clusters that unite them, should be carried out on the basis of unified databases, which, at a minimum, should contain:

- a list (register) of breakthrough technologies that are currently taking place in the world, highlighting aspects of their relationship with the sixth technological order;

- information about the distribution of educational institutions and the current state of affairs in the development of breakthrough technologies in them, taking into account the processes associated with the transition to the sixth technological order; 
- scientific and technological requests of specific enterprises for the introduction of breakthrough technologies, and which are associated with the processes of transition to the sixth technological order;

- predictive assessments of the feasibility of creating various industrial organizations and infrastructural institutions that will master breakthrough technologies under the auspices of certain educational institutions, and which are associated with the transition to the sixth technological order;

- formed bases of research topics of educational institutions with the obligatory allocation of arrays of breakthrough technologies and an indication of which educational institutions carry out research activities in the same direction and how this affects the processes associated with the transition to the sixth technological order;

- information on the formation of the educational process, taking into account the transition to the total implementation of the problems of breakthrough technologies in pedagogical technologies, which affect the processes of transition to the sixth technological order.

In this regard, it is necessary to dwell on the consideration of research competence in various spheres of life, which is formed on the basis of a specific set of needs (both of an individual and of contact groups). Depending on the level of embeddedness of research competence in the activity, it is possible to propose (using the theoretical apparatus of morphological analysis) a classification (Table 1).

To do this, we highlight several of the most significant aspects of division:

1) The mental orientation of the individual to the implementation of research activities. In this case, it is necessary to understand the connection and drift of innate and acquired properties (signs), which are fixed by the inner reality of the individual and, accordingly, the environment. The terms "extrovert" and "introvert" reflect this connection in a very rough way.

2) Own (individual) motivational apparatus that stimulates a person to carry out research activities. In this case, psychology should put in the hands of the educator and the learner the tools for increasing the effectiveness of the formation of acquired properties (attributes) of the personality for research activities. In this regard, it should be noted that recently a new area of psychological science and practice has been recorded - educational neuropsychology. Built on the ideas of L.S. Vygotsky and A.R. Luria educational neuropsychology is actively being introduced into psychological and pedagogical practice, and in many respects this area of science is based on the study of the problems of research competence in various spheres of life $[10,11]$.

3) The level of requirements and the presence of high-quality psychological support of the close external environment for the formation of acquired properties (attributes) in a person for the implementation of expedient research activities. The creation of a "dynamic typology of a learner" should proceed from the consideration of the internal structure and bifurcation changes in development. In this case, the concepts "norm" and "deviations" should refer to digital diagnostics.

4) The level of requirements and the presence of high-quality psychological support of the distant external environment for the formation of acquired properties (signs) in a person for the implementation of expedient research activities. In psychology in general and neuropsychology in particular, an idea has been formed about the uneven development of mental functions and their individual components, which is determined both by the species genetic program and the individual genetic program, as well as environmental influences.

5) The presence of a methodological and informational apparatus in an educational institution for the detection of congenital $\mathrm{x}$ and the personality's acquired inclinations to research activities. In this case, it is necessary to talk about intellectual medicine, which should accompany a person's actions and compare his research potential with the tasks that 
society puts before him. In this case, it is necessary to talk about neuropsychological test diagnostics, methods of "follow-up diagnostics" and, if necessary, methods of corrective and prognostic work.

Table 1. Morphological classification of the assessment of the magnitude of various aspects of division for the formation of acquired properties (signs) in a person for the implementation of expedient research activities

\begin{tabular}{|c|c|c|c|c|c|c|}
\hline \multirow[t]{2}{*}{ № } & \multirow[t]{2}{*}{ Fission aspect } & \multicolumn{5}{|c|}{$\begin{array}{l}\text { A variant of estimating the magnitude of the aspect } \\
\text { ratio }\end{array}$} \\
\hline & & $\begin{array}{l}\text { Minimum } \\
1 .\end{array}$ & $\begin{array}{c}\text { Small } \\
2\end{array}$ & $\begin{array}{l}\text { Medium } \\
\quad 3\end{array}$ & $\begin{array}{l}\text { Large } \\
4 .\end{array}$ & $\begin{array}{l}\text { Maximum } \\
\quad 5 .\end{array}$ \\
\hline 1. & $\begin{array}{l}\text { The mental orientation of the } \\
\text { individual to the implementation of } \\
\text { research activities. }\end{array}$ & 1.1. & 1.2. & 1.3. & 1.4. & 1.5. \\
\hline 2. & $\begin{array}{l}\text { Own (individual) motivational } \\
\text { apparatus that stimulates a person to } \\
\text { carry out research activities. }\end{array}$ & 2.1 . & 2.2 & 2.3. & 2.4 & 2.5 \\
\hline 3. & $\begin{array}{l}\text { The level of requirements and the } \\
\text { presence of high-quality psychological } \\
\text { support of the close external } \\
\text { environment for the formation of } \\
\text { acquired properties (signs) in a person } \\
\text { for the implementation of expedient } \\
\text { research activities }\end{array}$ & 3.1 & 3.2. & 3.3. & 3.4. & 3.5. \\
\hline 4. & $\begin{array}{l}\text { The level of requirements and the } \\
\text { presence of high-quality psychological } \\
\text { support of the distant external } \\
\text { environment for the formation of } \\
\text { acquired properties (signs) in a person } \\
\text { for the implementation of expedient } \\
\text { research activities }\end{array}$ & 4.1. & 4.2. & 4.3. & 4.4.. & 4.5. \\
\hline 5. & $\begin{array}{l}\text { The presence of a methodological and } \\
\text { informational apparatus in an } \\
\text { educational institution to identify } \\
\text { innate and acquired personality } \\
\text { inclinations to research activities. }\end{array}$ & 5.1 & 5.2. & 5.3. & 5.4 & 5.5 . \\
\hline
\end{tabular}

The classification proposed in Table 1 makes it possible to assess the magnitude of various aspects of division for the formation of acquired properties (signs) in a person for the implementation of expedient research activities. Thus, the system of research competence for a specific educational institution, including various aspects of its functioning, can be represented in a code dimension. For example, code 1.1. suggests that the educational institution is not interested in the mental orientation of the individual (which needs to be clarified) to carry out research activities. The experience of the authors shows that the modern system of selection of applicants, as a rule, is far from assessing the mental orientation of a person to carry out research activities, that is, the system of research competence of a future student, when enrolling in a university.

When considering two educational institutions, for example, with the following code characteristics:

- the first educational institution has the following set of code characteristics: 1.3. - 2.2. - 3.2. - 4.1. - 5.1.;

- the second educational institution has the following set of code characteristics: 1.3. 2.4. - 3.2. - 4.1. - 5.3.

It is obvious that the second educational institution has a higher research potential. 
The development of a code portrait of an educational institution can be carried out in the following sequence (methodology for developing a code portrait of an educational institution):

1) Compilation of a list of persons, dividing them into target groups that form the basic potential of the research activity of an educational institution (higher educational institution), and who must undergo test procedures in terms of the level of development of research competence.

2) Coding for each aspect of the division of each significant person (students and teachers) of the level of formation of research competence on the basis of a specially created questionnaire.

3) Averaging the data obtained and determining the average for an educational institution for each target group.

4) Averaging the data obtained and determining the average for an educational institution.

5) Development of activities for each target group, which form the basic potential of the research activity of an educational institution (university), to increase the level of research competence.

6) Monitoring the quality of implementation of the developed measures for each target group to increase the level of research competence.

The proposed sequence for the development of a code portrait allows the entire set of educational institutions to be divided according to the level of the state of the system of research competence, which gives the management apparatus of the university a powerful mechanism for the formation of acquired properties (attributes) in a person for the implementation of expedient research activities (creation of the necessary volume and focus of research competence of students and trainees). To do this, it is necessary to analyse the activities of the educational institution in all five aspects of the division.

As an example, consider the comparison of two educational systems: domestic (Russian) and foreign (American) based on the proposed methodology. For this, five educational institutions were selected in Russia (Table 2) and the United States (Table 3).

At the same time, obtaining a volumetric characteristic according to the level of availability in an educational institution (university) of a system for the formation of acquired properties (attributes) in a person to carry out expedient research activities (creating the necessary volume and focus of research competence of students and trainees) should be carried out, at least in the following areas:

- identification of the properties of interest among applicants and the development of a general portrait in terms of the volume and focus of the research competence of future students;

- identification of the properties of interest among the teaching staff (teaching staff) and the development of a general portrait in terms of the volume and focus of research competence with the preparation of plans to achieve the required characteristics of teaching staff;

- monitoring of the properties of interest in students and the development of a general portrait of changes in the volume and focus of research competence with the preparation of plans to achieve the necessary characteristics;

- creation of an educational cluster with the identification of properties of interest in persons interacting or intending to interact (future applicants or those wishing to receive additional education at a university) and the development of a general portrait of an educational cluster in terms of the volume and focus of research competence. 
Table 2. Expert code portraits (five selected for analysis) of educational institutions in

\begin{tabular}{|c|c|c|c|c|c|}
\hline \multicolumn{6}{|c|}{ Russia } \\
\hline $\begin{array}{l}\text { Name of } \\
\text { educational } \\
\text { institution }\end{array}$ & $\begin{array}{c}\text { The } \\
\text { mental } \\
\text { orientati } \\
\text { on of the } \\
\text { individu } \\
\text { al to the } \\
\text { impleme } \\
\text { ntation } \\
\text { of } \\
\text { research } \\
\text { activities }\end{array}$ & $\begin{array}{c}\text { Own } \\
\text { (individual) } \\
\text { motivational } \\
\text { apparatus } \\
\text { that } \\
\text { stimulates a } \\
\text { person to } \\
\text { carry out } \\
\text { research } \\
\text { activities }\end{array}$ & $\begin{array}{l}\text { The level of } \\
\text { requirements } \\
\text { and the presence } \\
\text { of high-quality } \\
\text { psychological } \\
\text { support of the } \\
\text { close external } \\
\text { environment for } \\
\text { the formation of } \\
\text { acquired } \\
\text { properties } \\
\text { (signs) in a } \\
\text { person for the } \\
\text { implementation } \\
\text { of purposeful } \\
\text { research } \\
\text { activities }\end{array}$ & $\begin{array}{l}\text { The level of } \\
\text { requirements } \\
\text { and the presence } \\
\text { of high-quality } \\
\text { psychological } \\
\text { support of the } \\
\text { distant external } \\
\text { environment for } \\
\text { the formation of } \\
\text { acquired } \\
\text { properties } \\
\text { (attributes) in a } \\
\text { person for the } \\
\text { implementation } \\
\text { of purposeful } \\
\text { research } \\
\text { activities }\end{array}$ & $\begin{array}{l}\text { The presence } \\
\text { of a } \\
\text { methodologic } \\
\text { al and } \\
\text { informational } \\
\text { apparatus in } \\
\text { an educational } \\
\text { institution to } \\
\text { identify } \\
\text { congenital and } \\
\text { acquired } \\
\text { personality } \\
\text { tendencies } \\
\text { towards } \\
\text { research } \\
\text { activities }\end{array}$ \\
\hline $\begin{array}{c}\text { State } \\
\text { University of } \\
\text { Management }\end{array}$ & 1.3 & 2.2 & 3.3 & 4.3 & 5.1 \\
\hline $\begin{array}{l}\text { National } \\
\text { Research } \\
\text { Nuclear } \\
\text { University } \\
\text { "MEPhI" }\end{array}$ & 1.3 & 2.3 & 3.4 & 4.3 & 5.1. \\
\hline $\begin{array}{c}\text { Saint } \\
\text { Petersburg } \\
\text { State } \\
\text { University }\end{array}$ & 1.3 & 2.2 & 3.3 & 4.3 & 5.1 \\
\hline $\begin{array}{c}\text { State } \\
\text { University } \\
\text { "Dubna" }\end{array}$ & 1.4 & 2.3 & 3.4 & 4.4 & 5.1 \\
\hline $\begin{array}{c}\text { Novosibirsk } \\
\text { State } \\
\text { University }\end{array}$ & 1.4 & 2.3 & 3.4 & 4.3 & 5.1 \\
\hline
\end{tabular}

Table 3, using the example of the Northwestern University of the United States, provides a description of the code components of the portrait. To increase the objectivity and versatility of the assessment, each aspect of the division is based on a system of indicators that are evaluated by experts. For example, one of the indicators of such an aspect of division as the mental orientation of a person to carry out research activities is the provision of students with scientific / research laboratories of an educational institution (the ratio of the number of scientific / research laboratories of an educational institution to the number of students). This indicator is focused on the needs of quality management and research work of an educational institution, thereby showing its capabilities for the development of personality inclinations to research activities. 
Table 3. Expert code portraits (five selected for analysis) of US educational institutions

\begin{tabular}{|c|c|c|c|c|c|}
\hline $\begin{array}{l}\text { Name of } \\
\text { educational } \\
\text { institution }\end{array}$ & $\begin{array}{l}\text { The mental } \\
\text { orientation of } \\
\text { the individual } \\
\text { to the } \\
\text { implementatio } \\
\text { n of research } \\
\text { activities }\end{array}$ & $\begin{array}{c}\text { Own } \\
\text { (individual) } \\
\text { motivational } \\
\text { apparatus } \\
\text { that } \\
\text { stimulates a } \\
\text { person to } \\
\text { carry out } \\
\text { research } \\
\text { activities }\end{array}$ & $\begin{array}{l}\text { The level of } \\
\text { requirements } \\
\text { and the presence } \\
\text { of high-quality } \\
\text { psychological } \\
\text { support of the } \\
\text { close external } \\
\text { environment for } \\
\text { the formation of } \\
\text { acquired } \\
\text { properties } \\
\text { (signs) in a } \\
\text { person for the } \\
\text { implementation } \\
\text { of purposeful } \\
\text { research } \\
\text { activities }\end{array}$ & $\begin{array}{l}\text { The level of } \\
\text { requirements } \\
\text { and the } \\
\text { presence of } \\
\text { high-quality } \\
\text { psychological } \\
\text { support of the } \\
\text { distant } \\
\text { external } \\
\text { environment } \\
\text { for the } \\
\text { formation of } \\
\text { acquired } \\
\text { properties } \\
\text { (attributes) in } \\
\text { a person for } \\
\text { the } \\
\text { implementatio } \\
\text { n of } \\
\text { purposeful } \\
\text { research } \\
\text { activities }\end{array}$ & $\begin{array}{l}\text { The } \\
\text { presence of } \\
\text { a } \\
\text { methodologi } \\
\text { cal and } \\
\text { information } \\
\text { al apparatus } \\
\text { in an } \\
\text { educational } \\
\text { institution to } \\
\text { identify } \\
\text { congenital } \\
\text { and } \\
\text { acquired } \\
\text { personality } \\
\text { tendencies } \\
\text { towards } \\
\text { research } \\
\text { activities }\end{array}$ \\
\hline $\begin{array}{l}\text { Northwestern } \\
\text { University } \\
\text { (one of the } \\
\text { most difficult } \\
\text { educational } \\
\text { institutions in } \\
\text { the country) }\end{array}$ & $\begin{array}{c}1.4 \\
\text { University } \\
\text { research takes } \\
\text { place in } 1,500 \\
\text { laboratories, } \\
\text { many of } \\
\text { which are also } \\
\text { available to } \\
\text { students }\end{array}$ & $\begin{array}{c}\text { 2.4. } \\
\text { Many } \\
\text { students } \\
\text { devote their } \\
\text { first two } \\
\text { years to } \\
\text { finding a } \\
\text { specialty } \\
\text { that is right } \\
\text { for them. }\end{array}$ & $\begin{array}{c}3.5 . \\
\text { Students have } \\
\text { the opportunity } \\
\text { to engage in } \\
\text { scientific } \\
\text { research, } \\
\text { regardless of the } \\
\text { school. The } \\
\text { Founders } \\
\text { Scholarship is } \\
\text { awarded to } \\
\text { students from } \\
\text { middle-income } \\
\text { families. The } \\
\text { student's } \\
\text { academic and } \\
\text { research } \\
\text { achievements } \\
\text { are considered }\end{array}$ & $\begin{array}{c}4.4 . \\
\text { NU Medical } \\
\text { School has a } \\
\text { global } \\
\text { medicine } \\
\text { center that } \\
\text { conducts } \\
\text { advanced } \\
\text { research in } \\
\text { more than } \\
\text { twenty } \\
\text { countries } \\
\text { around the } \\
\text { world. }\end{array}$ & $\begin{array}{l}\text { 5.5. Experts } \\
\text { from } \\
\text { Northwester } \\
\text { n University } \\
\text { prove that } \\
\text { the human } \\
\text { brain } \\
\text { develops in } \\
\text { the process } \\
\text { of learning } \\
\text { new } \\
\text { languages }\end{array}$ \\
\hline $\begin{array}{c}\text { University of } \\
\text { Chicago }\end{array}$ & 1.5 & 2.4. & 3.4 . & 4.3. & 5.3. \\
\hline $\begin{array}{c}\text { University of } \\
\text { California at } \\
\text { Berkeley }\end{array}$ & 1.4 . & 2.3. & 3.3. & 4.2. & 5.2 \\
\hline $\begin{array}{l}\text { Columbia } \\
\text { University }\end{array}$ & 1.4 . & 2.4 & 3.4 . & 4.4 . & 5.4 . \\
\hline $\begin{array}{l}\text { University of } \\
\text { Washington }\end{array}$ & 1.4 . & 2.4 . & 3.5 . & 4.4. & 5.3. \\
\hline
\end{tabular}

A comparative analysis of expert code portraits of educational institutions in Russia and the United States showed that American universities have a high research potential, the use of project management methods (PERT, CPM, PRINCE / PRINCE2, PLC, etc.) in the management of research projects at the university; use a system of selection of applicants, 
which at its core contains an assessment of the mental orientation of a person to training, including research activities; apply an individual trajectory of learning, aimed at preparing a student capable of systematic thinking, correct value judgments and creative activity.

\section{Conclusion}

The implementation of the proposed methodology for the development of a code portrait of an educational institution, which is formed on the basis of a specific set of needs (both of an individual and of contact groups), will contribute to the creation in an educational institution of a mechanism for the formation of acquired properties (attributes) in a person for the implementation of expedient research activities (creation of the necessary the volume and focus of the research competence of students and trainees).

In the process of research and practical implementation of the results, the authors of the article proposed a methodology for developing a code portrait of an educational institution, which is formed on the basis of a specific set of needs (both of an individual and of contact groups). The results of the study are relevant in the context of developing the country's educational strategy to match the educational needs of the state, business, society, and individual participants in the educational process with the available resources.

\section{References}

1. E. Faure and others. Learning to Be: The World of Education Today and Tomorrow. Paris: United Nations Educational, Scientific and Cultural Organization (1972).

2. J. E. Seaman, I. E. Allen Grade Increase: Tracking Distance Education in the United States. Babson Survey Research Group (2018).

3. G.R. Bikkulova Principles of distance learning as a reflection of modern requirements for the educational process. Bulletin of the Russian State Pedagogical University. A.I. Herzen. 60, 332-335 (2008).

4. M. Murdoch T. Muller Explosion of learning. Nine rules for an effective virtual classroom - M.: Alpina Publisher (2012).

5. J. Henry, J. Meadows. An Absolutely Riveting Online Course: Nine Principles for Excellence in Web-based Teaching. Canadian Journal of Learning and Technology. 34 (1) (2008).

6. L.N. Baranova Stages of development of academic mobility of students in the system of higher education in Canada. Problems of Pedagogy. 6 (38), 33-41 (2018).

7. V.V. Nasonkin National and regional dimension of state educational policy in the context of globalization (on the example of the EU): author. dis. ... dr. polit. sciences. St. Petersburg, 387. (2015).

8. O.V. Zinevich, E.V. Zakharova From education to entrepreneurship: experience of modernization of universities in South Korea. Power. 25 (12), 143-151. (2017).

9. N. Antonopoulos, G. Lee Cloud Computing Principles, Systems and Applications. Springer London Dordrecht New York Heidelberg. 382 (2010).

10. L.S. Vygotsky The problem of development and disintegration of higher mental functions. Problems of defectology. M., 404-418. (1995).

11. A.R. Luria, L.S. Vygotsky The problem of localization of functions. Questions of psychology. 6. 55-61. (1996). 